\title{
Opsoclonus-myoclonus syndrome associated with cytomegalovirus encephalitis
}

Figure The patient with the opsoclonus-myoclonus syndrome associated with cytomegalovirus encephalitis (see video)

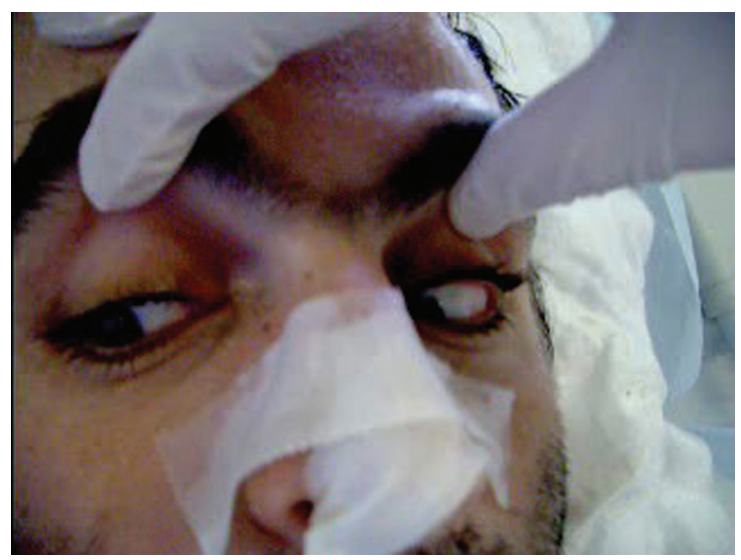

VIDEO A 30-year-old man was admitted because of febrile respiratory infection and confusion. A lumbar puncture revealed mild pleocytosis and elevated protein. Continuous conjugate eye oscillations in horizontal, rotatory, and vertical direction and diffuse myoclonus were observed (figure; see video on the Neurology Web site at www.neurology.org). Cytomegalovirus (CMV) encephalitis was diagnosed on the basis of positive PCR and high IgG titers in the CSF and rising serum IgM and IgG titers. Brain MRI and HIV serology were negative. The patient was treated with ganciclovir, steroids, and immunoglobulins with remarkable recovery. The opsoclonus-myoclonus syndrome (OMS) is caused by infections and neoplasms. ${ }^{1,2}$ CMV infection should be considered in OMS cases.

I. Zaganas, MD, PhD; G. Prinianakis, MD; N. Xirouchaki, MD; and M. Mavridis, MD, PhD, Crete, Greece

Address correspondence and reprint requests to Dr. M. Mavridis, Neurology Department, University Hospital of Heraklion, Voutes, Crete, Greece; mavridis@her.forthnet.gr

Supplemental data at www.neurology.org
Disclosure: The authors report no conflicts of interest.

\section{REFERENCES}

1. Caviness J, Forsyth P, Layton D, McPhee T. The movement disorder of adult opsoclonus. Mov Disord 1995;10:22-27.

2. Verma A, Brozman B. Opsoclonus-myoclonus syndrome following Epstein-Barr virus infection. Neurology 2002;58:11311132. 


\section{Neurology}

Opsoclonus-myoclonus syndrome associated with cytomegalovirus encephalitis

I. Zaganas, G. Prinianakis, N. Xirouchaki, et al.

Neurology 2007;68;1636

DOI 10.1212/01.wnl.0000262766.50747.27

This information is current as of May 7, 2007

Updated Information \&

Services

Supplementary Material

References

Subspecialty Collections

Permissions \& Licensing

Reprints including high resolution figures, can be found at: http://n.neurology.org/content/68/19/1636.full

Supplementary material can be found at: http://n.neurology.org/content/suppl/2007/05/01/68.19.1636.DC1

This article cites 2 articles, 1 of which you can access for free at: http://n.neurology.org/content/68/19/1636.full\#ref-list-1

This article, along with others on similar topics, appears in the following collection(s):

All Infections

http://n.neurology.org/cgi/collection/all_infections

Encephalitis

http://n.neurology.org/cgi/collection/encephalitis

Myoclonus; see Movement Disorders/myoclonus

http://n.neurology.org/cgi/collection/myoclonus_see_movement_disord ers-myoclonus

Ocular motility

http://n.neurology.org/cgi/collection/ocular_motility

Information about reproducing this article in parts (figures,tables) or in its entirety can be found online at:

http://www.neurology.org/about/about_the_journal\#permissions

Information about ordering reprints can be found online:

http://n.neurology.org/subscribers/advertise

Neurology ${ }^{\circledR}$ is the official journal of the American Academy of Neurology. Published continuously since 1951, it is now a weekly with 48 issues per year. Copyright . All rights reserved. Print ISSN: 0028-3878. Online ISSN: 1526-632X.

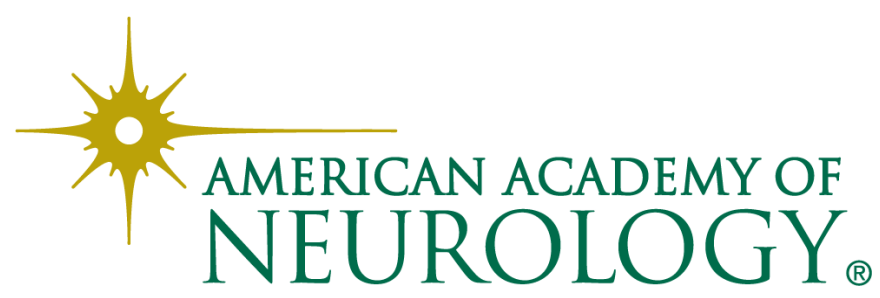

